\title{
Fodder and Grain Yield in Native Maize (Zea mays L.)
}

Escalante-Estrada, J. Alberto ${ }^{1 *} ;$ Rodríguez-González, M.T. ${ }^{1}$; Escalante-Estrada Y. I. ${ }^{2}$

${ }^{1}$ Colegio de Postgraduados Postgrado en Botánica. Campus Montecillo. Montecillo Texcoco, México. ${ }^{2}$ Universidad Autónoma de Guerrero, Instituto de Investigación Científica área de Ciencias Naturales, Chilpancingo Guerrero México.

*Corresponding Author: jasee(acolpos.mx

\begin{abstract}
Objective: To quantify the grain yield, biomass, crop stubble, and leaf:stalk index in seven varieties of maize (Zea mays L.), as well as the relationship between biomass, stubble, and plant height.

Design/Methodology/Approach: The process consisted in planting seven genotypes of native maize (Zea mays L.). The experimental design comprised randomized blocks with four repetitions. The plant's height, total biomass, its accumulation in stalk, leaf, husk, cob, grain, and stubble (biomass of stalk+leaf+husk+cob) were evaluated. A variance analysis, the Tukey means comparison test, and a regression analysis were applied.

Results: Significant differences were found between the native maize genotypes. Notable cases were the Ixtenco Yellow, followed in terms of biomass and stubble by the Texcoco White-Wide, then the Ixtenco White and Red. The plant height determined biomass in $67 \%$ and stubble in $77 \%$.

Study Limitations/Implications: The tendencies found could vary depending on the native cultivars studied and their management.

Findings/Conclusions: In the study region, there are differences between native maize cultivars for the agronomic characteristics evaluated. With respect to the yield of grain, biomass, and stubble, the Ixtenco Yellow cultivar was outstanding, followed by the Texcoco White-Wide, and Ixtenco White and Red. The plant height determined biomass in $67 \%$, and stubble quantity in $77 \%$.
\end{abstract}

Keywords: Dry matter, stalk, leaf, grain, stubble.

\section{INTRODUCTION}

In MexiCO, $\begin{aligned} & \text { native or Creole maize (Zea mays L.) is cultivated principally by producers that } \\ & \text { employ trational agriculture with multiple uses, such as grain production, }\end{aligned}$ fodder, tortillas, tamale wrapping, butter, container and artisanal products (Ávila-Bello et al., 2016). The INEGI (2014) observes that $82 \%$ of the maize-cultivated surface area in Mexico consists of Creole or native varieties, which in addition to being adapted to the producers' climate and technological conditions, possess characteristics

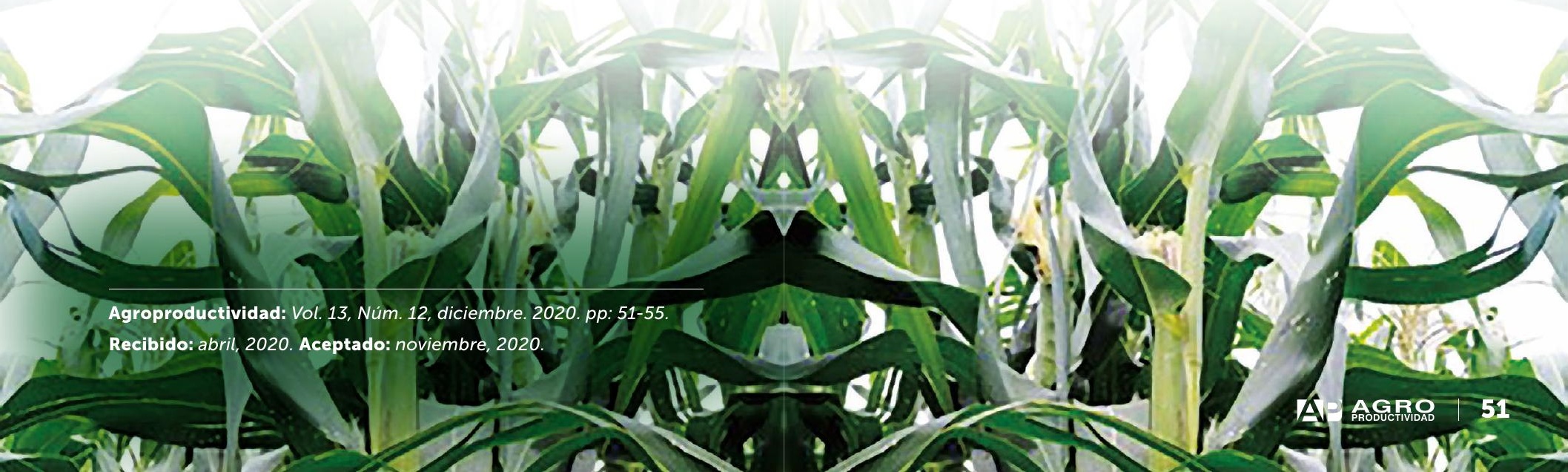


that respond to the culinary tastes of populations and cultures. The sowing of Creole maize seeds has generated a highly biodiverse phytogenetic resource, with more than 50 recognized native varieties (Kato et al., 2009). Escalante et al. (2013) report genetic variability in stubble production, total biomass, yield, and specific leaf area in native maize cultivars. Escalante and Rodríguez (2016) report a biomass (dry matter) of 608 $\mathrm{g} \mathrm{m}^{-2}$ and a yield of $209 \mathrm{~g} \mathrm{~m}^{-2}$, with $2.45 \mathrm{~m}$ height, in Blue San Miguel Tlaixpan native maize sown under 330 $\mathrm{mm}$ rainfall. Aguilar et al. (2016) report that the native maize Michoacán 21, cultivated in Montecillo, Mexico, during the rainy season, showed a biomass of $860 \mathrm{~g}$ $\mathrm{m}^{-2}$ and a grain yield of $236 \mathrm{~g} \mathrm{~m}^{-2}$. At the maize's physiological maturity, the grain is harvested and the rest of the plant (stubble) is used as fodder for livestock (Hellin et al., 2013; Reyes-Muro et al., 2013; Beuchelt et al., 2015). From the maize stubble, the leaves are the most digestible for ruminants due to their lower lignin content compared to the stalk (Williams et al., 1997). For every kilogram of grain produced, an estimated 1 $\mathrm{kg}$ of byproduct is obtained. The stubble represents an average of $50 \%$ of the total aerial biomass (Dhugga, 2007). The leaf:stalk index (proportion of dry matter in leaves with respect to the stalk), indicates the quantity and quality of leaf fodder. Another byproduct is the olote or cob, that can be used as a mulching substrate for humidity retention (Rodríguez-Martínez et al., 2016), to develop nitrogenous fertilizers with prolonged or slow-release action (Kabel et al., 2007; Córdoba et al., 2013), or else for ethanol production (García and Garza, 2016). The studies on production of grain, biomass, stubble, and agronomic characteristics of native maize are uncommon, therefore the objective of this study was to determinate in native maize cultivar: a) the grain yield, biomass production, stubble quantity, leaf:stalk index, and agronomic characteristics; and b) the relationship between the production of biomass, stubble, and the plant's height.

\section{MATERIALS AND METHODOLOGY}

The study was conducted in Montecillo, Texcoco, State of Mexico (19 $29^{\prime} \mathrm{N}, 98^{\circ} 53^{\prime} \mathrm{W}$, at 2250 m altitude), with a temperate climate, light rainfall, mean annual temperature of $14.6{ }^{\circ} \mathrm{C}$, and $558.5 \mathrm{~mm}$ precipitation (García, 2004), in clay soil with $\mathrm{pH}$ of 7.8 . The treatments consisted in sowing seven cultivars (horticultural varieties, cvs) of native maize (Zea mays L.) of different origins, sown by the farmers close to the region of Montecillo, Texcoco, Mexico (Table 1$)$, at a density of 4.16 plants $\mathrm{m}^{-2}(80 \times 30$ $\mathrm{cm}$ ) and with 100-100-00 of NPK. The experimental unit was four $5 \mathrm{~m}$ long furrows.

The experimental design was in random blocks with four repetitions. The phenological stages were registered, as well as maximum (Tmax) and minimum (Tmin) temperature, and rainfall (PP, $\mathrm{mm}$ ) during the crop's development. At harvest, 15 plants were taken from the useful plot to register the plant height $(A L T, \mathrm{~cm})$, total biomass of the aerial part (TB, dry matter $\mathrm{g} \mathrm{m}^{-2}$ ), its accumulation (DMA) and distribution in the stalk, leaves, husks, cob, grain (yield, GR), stubble (TB-GR), and the leaf:stalk index (accumulated biomass in leaf/ accumulated biomass in stalk). The study variables were analyzed with the SAS package, version 9.0 (SAS, 2003), with variance analysis (ANOVA), and for treatments with significant differences, the means comparison test (Tukey $\alpha=0.05$ ) was used. A regression analysis was carried out to determine the relationship between total biomass and stubble production and the plant height, and between biomass production and stubble.

\section{RESULTS AND DISCUSSION}

Phenological phases occurred 9 d after sowing (das) until emergence, flowering (F) between 70 and 80 das, and harvesting at $140 \mathrm{~d}$. During the crop's development, the average Tmax was $27^{\circ} \mathrm{C}$ and the $\operatorname{Tmin}, 8^{\circ} \mathrm{C}$, and the $\mathrm{PP}$ added up to $350 \mathrm{~mm}$. For the plant height, significant differences were observed between cultivars (cvs). The

\begin{tabular}{|c|c|c|c|c|c|}
\hline Location & Landrace maize & Coordinates & $\begin{array}{l}\text { Height above } \\
\text { sea level }(\mathrm{m})\end{array}$ & $\begin{array}{c}\text { Mean annual } \\
\text { temperature }\left({ }^{\circ} \mathrm{C}\right)\end{array}$ & $\begin{array}{l}\text { Annual } \\
\text { precipitation (mm) }\end{array}$ \\
\hline $\begin{array}{c}\text { Ixtenco Tlaxcala*- Temperate } \\
\text { climate (Cw) }\end{array}$ & $\begin{array}{l}\text { 1) Yellow } \\
\text { 2) White } \\
\text { 3) Red } \\
\text { 4) Black } \\
\text { 5) Pepitilla }\end{array}$ & $19^{\circ} 15^{\prime} \mathrm{N}, 97^{\circ} 53^{\prime} \mathrm{O}$ & 2542 & $11.1-16.1^{\circ} \mathrm{C}$ & 647 \\
\hline $\begin{array}{c}\text { Texcoco Edo. México. Temperate } \\
\text { climate }(\mathrm{Cw})\end{array}$ & $\begin{array}{l}\text { 1) White-Wide } \\
\text { 2) Blue }\end{array}$ & $19^{\circ} 29^{\prime} \mathrm{N}, 98^{\circ} 53^{\prime} \mathrm{O}$ & 2250 & $12.3-18.2^{\circ} \mathrm{C}$ & 610 \\
\hline
\end{tabular}

References: ${ }^{* h t t p: / / s i g l o . i n a f e d . g o b . m x / e n c i c l o p e d i a / E M M 29 t l a x c a l a / m u n i c i p i o s / 29016 a . h t m l ; ~ G a r c i ́ a ~(2004) . ~}$ 
Yellow cultivar (cv) showed plants with greater height at $231 \mathrm{~cm}$, followed by White $(215 \mathrm{~cm})$, and Red $(214 \mathrm{~cm})$. The lowest height corresponded to the White-Wide (200 $\mathrm{cm})$ and Pepitilla $(180 \mathrm{~cm})$ (Table 2).

Table 2 shows the results for total biomass (TB) and its accumulation in stalks, leaves, husks, cobs, and grains. The highest TB (977 $\mathrm{g} \mathrm{m}^{-2}$ ) corresponded to the Yellow genotype due mostly to a greater accumulation of DM (DMA) in the stalk, husks (totomoxtle) and grain; followed by the White genotypes ( $\left.845 \mathrm{~g} \mathrm{~m}^{-2}\right)$, Red $\left(856 \mathrm{~g} \mathrm{~m}^{-2}\right)$, White-Wide (842 $\mathrm{g} \mathrm{m}^{-2}$ ), Blue $\left(831 \mathrm{~g} \mathrm{~m}^{-2}\right)$, and Black (781 $\mathrm{g} \mathrm{m}^{-2}$ ). The lowest TB was registered in Pepitilla (573 $\mathrm{g} \mathrm{m}^{-2}$ ). TB production, with the exception of the Black genotype, exceeds the maximum reported for other native varieties, such as the Labrador (447 $\mathrm{g} \mathrm{m}^{-2}$ ), Blue $\left(608 \mathrm{~g} \mathrm{~m}^{-2}\right)$, and Michoacán $21\left(680 \mathrm{~g} \mathrm{~m}^{-2}\right)$ for similar study conditions (Escalante et al., 2013; Escalante and Rodríguez, 2016; Aguilar et al., 2016, respectively).

In terms of the DMA in leaves, White-Wide and Black presented the greatest value with 144 and $110 \mathrm{~g} \mathrm{~m}^{-2}$. The lower values corresponded to the rest of the genotypes that were statistically equal. With respect to the stalk, the White and Yellow genotypes were the ones with the greatest DMA with 312 and $285 \mathrm{~g} \mathrm{~m}^{-2}$, respectively. The inferior value corresponded to Pepitilla with $245 \mathrm{~g}$ $\mathrm{m}^{-2}$. Concerning the husks, the Yellow and White-Wide genotypes presented the highest values with 172 and 153 $\mathrm{g} \mathrm{m}^{-2}$. Regarding the cob, the Red maize presented the heaviest cobs (79 $\mathrm{g} \mathrm{m}^{-2}$ ), followed by the Black, Blue, Yellow and White $\left(52,37,39\right.$ and $36 \mathrm{~g} \mathrm{~m}^{-2}$, respectively). The lowest DMA corresponded to the Blue and Pepitilla maize (37 and $21 \mathrm{~g} \mathrm{~m}^{-2}$ ). The highest GR was presented by Yellow and Red maize with 394 and $377 \mathrm{~g} \mathrm{~m}^{-2}$, which surpassed the GR of other native types (Escalante and Rodríguez, 2016; Aguilar et al., 2016), followed by the White, Black, and Blue maize. The inferior values corresponded to White-Wide and Pepitilla maize with 234 and $160 \mathrm{~g} \mathrm{~m}^{-2}$, respectively. Notably, the genotypes that stand out for TB production and GR were Yellow, White, Red, Blue and Black (Table 2). Generally, 34\% of DMA was in the stalk, $12 \%$ in leaves, $13 \%$ in husks, $5 \%$ in cobs, and $36 \%$ in grain.

\section{Stubble Production and Leaf:Stalk Index}

White-Wide and Yellow maize showed the highest production of stubble (609 and $583 \mathrm{~g} \mathrm{~m}^{-2}$, respectively), compared to other evaluated varieties, followed in stubble by Blue and White maize, then Black and Red, and the low value corresponded to Pepitilla (Table 3). On average, stubble represented $65 \%$ of TB, which exceeds that indicated by Dhugga (2007) by 50\%. Regarding leaf DMA with regards to the stalk (leaf:stalk) (Table 3), the

\begin{tabular}{|c|c|c|}
\hline Cultivar & Leaf:stalk & Stubble $\left(\mathrm{g} \mathrm{m}^{-2}\right)$ \\
\hline Yellow & $0.30 \mathrm{bc}$ & $583 a$ \\
\hline White & $0.27 c$ & $538 \mathrm{~b}$ \\
\hline Red & $0.36 \mathrm{~b}$ & $479 c$ \\
\hline Black & $0.44 a b$ & $483 b c$ \\
\hline Pepitilla & $0.35 b$ & $413 d$ \\
\hline White-Wide & $0.53 a$ & $609 a$ \\
\hline Blue & $0.28 \mathrm{bc}$ & $556 a b$ \\
\hline Probability of F. & $\star \star$ & ** \\
\hline Tukey 0.05 & 0.11 & 55 \\
\hline
\end{tabular}

** $P>0.01$. In columns values with similar letter are statistically equal according to Tukey 0.05 .

\begin{tabular}{|c|c|c|c|c|c|c|c|}
\hline Cultivar & Height (cm) & Stem & Leaf & Bracts & Cob & Grain & Total \\
\hline White & $215 b$ & 312 a & $85 b$ & $103 b$ & $36 \mathrm{~b}$ & $309 a b$ & $845 b$ \\
\hline Red & $214 b c$ & $252 b$ & $92 b$ & $56 c$ & 79 a & $377 a$ & $856 \mathrm{~b}$ \\
\hline White-Wide & $200 \mathrm{bcd}$ & $271 a b$ & $144 \mathrm{a}$ & $153 \mathrm{a}$ & $40 \mathrm{bc}$ & $234 c$ & $842 b$ \\
\hline Blue & $210 \mathrm{bc}$ & $306 a$ & $86 b$ & $127 \mathrm{ab}$ & $37 b$ & $275 b$ & $831 b$ \\
\hline Probability of $\mathrm{F}$. & $\star *$ & $\star \star$ & 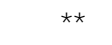 & $\star *$ & $\star \star$ & $\star \star$ & $* *$ \\
\hline Tukey 0.05 & 15 & 48 & 43 & 57 & 20 & 66 & 59 \\
\hline
\end{tabular}

** $P>0.01$. In columns values with similar letter are statistically equal according to Tukey 0.05 . 
outstanding maize varieties were White-Wide (0.53) and Black (0.44), with values exceeding those reported by Amador and Boschini (2000) for Creole maize (0.37), followed by Red (0.36), Pepitilla (0.35), and the inferior values were from Yellow (0.30), Blue (0.28), and White (0.27) maize. This suggests that if the principal use is for fodder, the most appropriate varieties would be White-Wide and Yellow for their higher proportion of leaves compared to the stalk, which implies more palatability for livestock.

\section{Biomass and Stubble Relationship with Stalk Height}

After performing a regression analysis for biomass and stubble with respect to plant height, it was found that the plant height $(\mathrm{cm})$ presented a determination coefficient $\left(R^{2}\right)$ of 0.67 and 0.77 , respectively, which indicates that the changes in TB and stubble depend on 67 and $77 \%$, respectively, with changes in plant height. The equations that can estimate biomass and stubble in function of the plant height are shown in Figures 1 and 2. Similar tendencies in relation to TB and plant height have been reported in other native maize varieties by Escalante et al. (2017), which indicates that the plant height can be a variable to be included in prediction models for TB and stubble.

\section{Stubble-to-Biomass Ratio}

Figure 3 shows that the changes in stubble were determined in $69 \%$ by changes in biomass. This indicates that plants with higher TB are required to obtain a greater amount of stubble. The Figure 3 equation indicates that for every gram of biomass, $0.69 \mathrm{~g}$ would correspond to stubble for the studied maize cultivars.

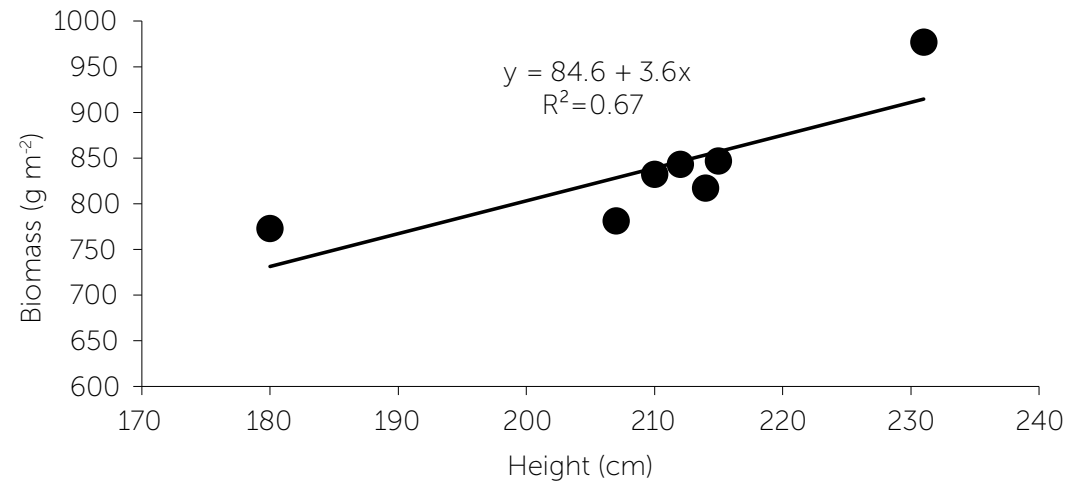

Figure 1. Relationship between biomass $\left(\mathrm{g} \mathrm{m}^{-2}\right)$ and plant height $(\mathrm{cm})$ in landrace maize. Montecillo, Texcoco Mexico, Mexico. Summer 2018.

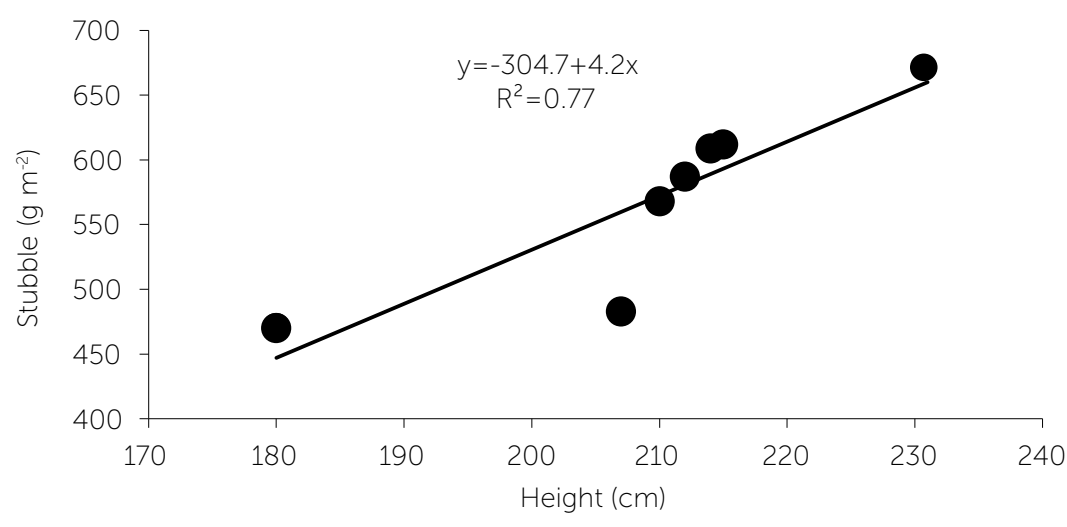

Figure 2. Relationship between stubble $\left(\mathrm{g} \mathrm{m}^{-2}\right)$ and plant height $(\mathrm{cm})$ in landrace maize. Montecillo, Texcoco Mexico, Mexico. Summer 2018.

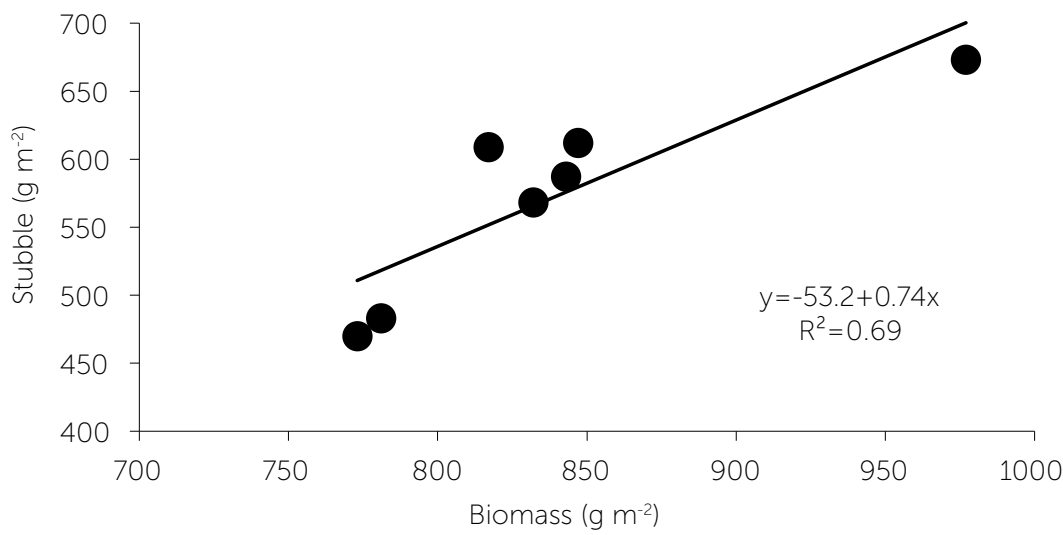

Figure 3. Relationship between stubble $\left(\mathrm{g} \mathrm{m}^{-2}\right)$ and biomass $\left(\mathrm{g} \mathrm{m}^{-2}\right)$ in landrace maize. Montecillo, Texcoco Mexico, Mexico. Summer 2018.

\section{CONCLUSIONS}

There are differences between native maize varieties in terms of grain yield, plant height, biomass production, accumulation in plant structures, stubble, and leaf:stalk ratio. The highest grain yield corresponded to the Ixtenco Yellow and Red, followed by the Ixtenco White and Black, and the Texcoco Blue. The lowest yield was found in Texcoco White-Wide and Ixtenco Pepitilla.
With respect to grain yield, biomass and stubble, the Ixtenco Yellow cultivar was the most outstanding, followed by the Texcoco White-Wide, and Ixtenco White and Red. The highest value in leaf:stalk index corresponded to the Texcoco White-Wide maize, followed by the Ixtenco Yellow, Red, and Black. Based on their coefficient of determination $\left(R^{2}\right)$, stubble and biomass quantity was acceptable in relation to plant 
height. This variable could be used in prediction models for biomass and stubble.

\section{REFERENCES}

Aguilar Carpio, C., Escalante Estrada J. Alberto S, Aguilar Mariscal I., Mejía Contreras J. A., Conde Martínez V. F. y Trinidad Santos A. 2016. Eficiencia agronómica, rendimiento y rentabilidad de genotipos de maíz en función del nitrógeno. Terra Latinoamericana 34: 419-429

Amador R., A. L. y Boschini F. C. 2000. Fenología productiva y nutricional de maíz para la producción de forraje. Agronomía Mesoamericana 11 (1).171-177.

Ávila-Bello C.H. Morales Z.J.A. y Paczca R.O.2016.Los maíces nativos de la Sierra de Santa María: guía para su identificación en campo. 1ạ. Edición. Universidad Veracruzana, Red Temática sobre el Patrimonio Biocultural.103 p.

Beuchelt, T. D. and Badstue, L. (2013). Gender, nutrition- and climatesmart food production: Opportunities and trade-offs. doi 10.1007/s12571-013-0290-8. Food Security, 5(5), 709-721.

Córdoba J.A, Salcedo E., Rodríguez R., Zamora J..F., Manríquez R. Contreras H., Robledo J., Delgado E..(2013). Caracterización y valoración química del olote: degradación hidrotérmica bajo condiciones subcríticas. Rev. Latinoamer. Quím. 41(3):171-184.

Dhugga K.S. Maize biomass yield and composition for biofuels .(2007) Crop Sci. 47:2211-2227.

Escalante Estrada J. Alberto S, Rodríguez González Ma.Teresa y Escalante Estrada Yolanda I. (2013). Área foliar específica, rastrojo y rendimiento de cultivares de maíz en clima templado. pp: 181-184. En: Libro memorias del IV Congreso Internacional de Manejo de Pastizales. ISBN: 978-607-715-165-4.

Escalante Estrada J. Alberto. S. y Rodríguez González M.T. (2016). Biomasa, rendimiento y sus componentes en maíz bajo inundación a partir de la floración. Memorias del IV Congreso Internacional y XVIII Congreso Nacional de Ciencias Agronómicas 20 al 22 de abril de 2016. Chapingo, México, México. 671-672

Escalante-Estrada José Alberto Salvador, María Teresa RodríguezGonzález José Alberto Salvador, Rojas Victoria N. J. y EscalanteEstrada Y. Isabel. (2017). Modelos empíricos que estiman el rendimiento de maíz nativo en función de sus componentes morfológicos y la biomasa. Compendio Investigativo de Academia Journals Celaya 2017. TOMO 9. Elibro Online con ISBN 978-1-939982-32-2

García E. (2004). Modificación al sistema de clasificación climática de Koppen para adaptarlo a las condiciones de la República Mexicana. Cuarta edición. UNAM. México, D.F. 217 p.

García V.P y Garza G.Y. (2016). Sacarificación y fermentación simultánea de olote pretratado. Revista Iberoamericana de las Ciencias Biológicas y Agropecuarias.5 (9):53-67.

Hellin, J.; Erenstein, O.; Beuchelt, T.; Camacho, C., and Flores, D. (2013). Maize stover use and sustainable crop production in mixed crop-livestock systems in Mexico. Field Crops Research, $153,12-21$

INEGI. Instituto Nacional de Estadística y Geografía (2014). Encuesta Nacional Agropecuaria ENA-2014. 40 p.

Kabel, M. A., Bos, G., Zeevalking, J., Voragen, A. G. J. \& Schols, H. A. (2007). Effect of pretreatment severity on xylan solubility and enzymatic breakdown of the remaining cellulose from wheat straw. Bioresource. Technol., 98, 2042.

Kato, Y. T.; Mapes, S. C.; Mera, O. L.; Serratos, H. J. y Bye, B. R. (2009). Origen y diversificación del maíz: una revisión analítica. UNAMCONABIO editores. Distrito Federal, México. 119 p

Reyes-Muro L.; Camacho-Villa T. C. y Guevara-Hernández F. (Coords.) (2013). Rastrojos: manejo, uso y mercado en el centro y sur de México. Instituto Nacional de Investigaciones Forestales, Agrícolas y Pecuarias. Libro Técnico Núm. 7. Pabellón de Arteaga, Aguascalientes, México. I-VIII, 1-242 p.

Rodriguez-Martinez N., Lucas-Ciriaco D. J., Noguez-Estrada J. y Sanchez-Herrera, S. G.(2016). Evaluación del sustrato de olote en la retención de humedad en el suelo para el cultivo de tomate (Lycopersicum esculentum Mill). Revista de Ciencias Naturales y Agropecuarias .3 (7): 25-34.

Statistical Analysis System (SAS Institute). (2003). SAS/STAT. User's Guide Release 9.1 ed, Cary, NC, USA

Williams T.O., Fernández-Rivera S. and Kelley T.G. (1997). The influence of socioeconomic factors on the availability and utilization of crop residues as animal feeds. In: Renard C (ed). Crop residues in sustainable mixed crop/livestock farming systems. Wallingford, UK: CAB International. p 25-29. 